\title{
A RECONSIDERATION OF PSEUDEPIGRAPHY IN EARLY CHRISTIANITY ${ }^{1}$
}

\author{
Jeremy Duff
}

This thesis examines the use of pseudepigraphy within Christianity during the first and second centuries A.D. In particular, it assesses the common claim that pseudepigraphy was seen simply as an accepted literary technique. Two methodological principles guide this investigation. First, early-Christian pseudepigraphy is viewed in its historical context, thus, for example, it is first-century views of Isaiah which are relevant, not modern understandings of the development of Isaiah. Second, this thesis examines discourse about authorship, authority and pseudonymity within ancient texts, rather than deducing attitudes to pseudonymity from texts which modern scholarship has identified as pseudonymous. These principles separate it from many other investigations of the topic.

Part One is a critique of modern approaches to early-Christian pseudepigraphy. First in Chapter 2 the development of the idea of early-Christian pseudepigraphy is traced from the period of the Reformation to Schleiermacher, the first scholar to present a reasoned case that a New Testament text was pseudonymous, and on to the beginning of the twentieth century. It is observed that from the very beginning the judgement that a New Testament text was pseudonymous was almost always closely followed by the claim that early-Christian pseudonymity was 'an accepted literary technique'. During this period, however, little was done to substantiate this claim. The development of the distinction between the scriptural texts and their religious message and the influence this had on discussion of pseudonymity is also noted.

Chapter 3 analyses more recent scholarship. First, various methodological questions are addressed over genre and the range of material with which early-Christian pseudepigraphy should be

1 Jeremy Duff, A Reconsideration of Pseudepigraphy in Early Christianity (unpublished Ph.D. thesis, Oxford University, 1998); supervisor Professor Chris Rowland. 
compared. It becomes clear that simplistic answers to the question of pseudonymity are unsatisfactory, as is the a priori restriction of the evidence to be considered to either Jewish or Pagan writings, or to writings of one particular genre. Then the analysis of various key early-Christian texts is examined and the lack of consensus is made clear. More agreement is manifest over the understandings of authorship in Hellenistic and Imperial Greek and Roman culture. Finally, various particular scholarly approaches to early-Christian pseudepigraphy are considered-the respect in which the past was held, the technique which one would use if writing pseudonymously, and the connection of pseudonymity with inspired prophecy.

Part Two contributes more directly to the debate by analysing in depth the textual evidence associated with various of the issues identified in Part One. Chapter 4 considers the concepts of literary property expressed in Pagan literature. Since this was identified in Chapter 3 as a matter of some consensus, this chapter is directed towards illustration rather than demonstration. Nevertheless three particular studies are undertaken - of the practices of the libraries and of scholars, of Galen's use of the Hippocratic corpus, and of the Neo-Pythagorean texts. These show the sophistication of textual criticism and the interest in authorship shared at least by the literary elite, and that even in a corpus such as the Hippocratic, authorship was seen to be vital for authority. It is also demonstrated that the Neo-Pythagoreans cannot be presented as an example of a group in which the accepted practice was for texts to be attributed to the group's founder. It is concluded that during the first two centuries A.D. Greeks and Romans generally saw text and author as closely linked, and were concerned about literary authenticity. The development of the idea of literary property among Greek is also examined: this reveals that it developed over a period of just a few centuries which casts further doubt on the use of exilic Jewish material to illustrate first-century A.D. Jewish attitudes.

Chapter 5 examines authorship and authority in first-century Judaism, because it is often claimed that Jews had little concern over authorship and that the early-Christians inherited this attitude. First, the ways in which the authors of the scriptures were perceived during the first century A.D. are considered. Analysis of Josephus, Philo, the Lives of the Prophets, of the idea of a cessation of prophecy and of a Rabbinic baraita on the authorship of the scriptures all suggest that this common claim is baseless-in fact the authority of the scriptures often seems to be connected to their 
authors. Apocalyptic is then studied at some length for the existence of many pseudonymous apocalyptic texts from the period around the first century A.D. has often been presented as evidence that pseudonymity was an accepted technique. Four competing explanations of apocalyptic pseudonymity are examined: that it was to enhance the authority of the texts; that it was due to the author's sense that was simply reinterpreting previous prophecy; that it was the result of ecstatic experiences; and that it was literary fiction. The last of these is shown to be very unlikely, but otherwise it is difficult to choose between the competing hypotheses, and indeed different of them, or even combinations of these basic hypotheses, may explain the pseudonymity of different apocalypses. Although no clear conclusion is drawn about apocalyptic pseudonymity, the examination makes clear that it cannot simply be asserted that the attributions of the apocalypses were widely taken to be intentionally fictitious. Finally, Rabbinic evidence contained within the Mishnah and Tosefta is considered. It is shown that although the Mishnah itself seems to attempt to minimise the significance of individual sages by exalting the majority, often anonymous, tradition, this appears to be against a background in which the teaching of certain individual sages was given authority because it was theirs. It is concluded that while it is difficult to assess first-century Jewish attitudes to authorship and authority, the evidence that is extant points to a close connection being made between the author of a text or piece of tradition and its authority.

Chapter 6 examines authority and authorship in early-Christian texts. First, the six passages which directly refer to questions of authorship are exegeted in detail: 2 Thessalonians 2:1-3 and 3:17, Dionysius of Corinth on interpolations, Serapion on the Gospel of Peter, Tertullian on the Acts of Paul, Tertullian on the gospel writers and the Muratorian Fragment. In each of these cases it is shown that, whatever the real motivation of the authors, they way they presented their arguments makes it clear that they assumed that their audience would see authorship and authority closely linked and would disapprove of pseudonymity. However, the majority of this evidence is from the latter part of the second century, and it has often been suggested that there was a discontinuity in Christian attitudes in the first half of the second century. For, it is argued, during the first century Christians had a predominantly Jewish attitude to authorship, but as the composition of the Church changed around the beginning of the second century Gentile 
attitudes became dominant. Furthermore the intra-Christian struggles during the second century caused sources of authority to be more closely defined. Therefore an examination is undertaken of the developments during the second century, with regard to the authority of the Jesus tradition and the influence of Marcion and Gnosticism. This shows that while concern over authenticity and authority grew during this period, there is nothing to support the idea that there was a discontinuity. Thus it is concluded that during the latter part of the second-century the attitude of Christians is clear -authority was closely tied to authority. Furthermore, although the position earlier than this is somewhat obscure it is quite possible to plot a trajectory from the concern expressed over the authenticity of authoritative works in 2 Thessalonians through various late firstcentury and second-century works to the detailed arguments of Irenaeus and Tertullian in which authority and authorship are bound together. The concern over authority and authenticity intensified during this period, but there was no discontinuity.

Chapter 7 returns to the question at the heart of the thesis: what was the attitude of early Christians to pseudepigraphy? It is concluded that, despite the limitations of the evidence, it is most likely to have been that the value of a text was closely connected to its true authorship; that pseudonymity was known about and generally seen as a deceitful practice to be condemned; and that texts which were thought to be pseudonymous were marginalised-if they were not it was because they were seen mistakenly as authentic. Finally some reflections are given on the implications of this thesis for the exegesis of New Testaments texts. It is suggested that the demonstration that it is unlikely that pseudonymity was seen as an accepted literary technique causes various theological and hermeneutical problems, for it would mean that any texts judged pseudonymous within the New Testament originally set out deliberately to deceive their readers as to their origins. In particular, it causes difficulties for a historical-critical approach since there is a dilemma over whether one interprets a text such as 2 Timothy against its 'real' background or should one enter into the 'story world' of the text (at which point one effectively moves from a historical-critical approach to a literary one). Thus contrary to the suggestion of much recent scholarship pseudonymity is a significant issue for Christian theology. An appendix considers the influence of the canon on the discussion of pseudepigraphy and the different ways in which the legitimacy of a pseudepigraphon can be considered. 